\title{
Botanical Criteria of Baharkish Rangeland in Quchan, Khorasan Razavi Province, IRAN
}

\section{${ }^{1}$ SAEED, JAHEDI POUR, $*^{2}$ ALIREZA, KOOCHEKI, ${ }^{3}$ MEHDI, NASSIRI MAHALLATI, ${ }^{4}$ PARVIZ, REZVANI MOGHADDAM}

\author{
${ }^{I}$ Department of Agronomy and Plant Breeding, Faculty of Agriculture, Ferdowsi \\ University of Mashhad International Campus, Mashhad, I.R of IRAN \\ ${ }^{* 2,3,4}$ Department of Agronomy and Plant Breeding, Faculty of Agriculture, \\ Ferdowsi University of Mashhad, Mashhad, I.R of IRAN \\ *Corresponding Author Email: akooch@um.ac.ir
}

\begin{abstract}
Rangelands are natural ecosystems containing a range of resources of genetic diversity and numerous plant species and its evaluation has always been essential. However, biodiversity is one of the most important components of habitat assessment and the identification and introduction of the flora of an area is one of the significant operations that can be used in order to optimize the utilization of the available natural resources. Baharkish rangeland is located at a distance of about $60 \mathrm{~km}$ south of the city of Quchan. The rangeland's average elevation is about $2069 \mathrm{~m}$ above sea level, with its lowest at $1740 \mathrm{~m}$ and highest at $2440 \mathrm{~m}$. Baharkish rangland in over a ten year period had the average annual rainfall of 337 $\mathrm{mm}$ and $998.2 \mathrm{~mm}$ evaporation as well as average annual temperature of $9.4^{\circ} \mathrm{C}$, respectivelly. The results of the research conducted in the spring of 2014, showed that the total study area includes 77 species from 22 families with Poaceae, Asteraceae, Lamiaceae, Fabaceae, Apiaceae and Brassicaceae being the dominant families with $18 \%, 13 \%, 12 \%, 9 \%, 8 \%$ and $6 \%$ respectively. Classification of life form according to Raunkiaer method showed the dominance of the hemicryptophytes with the greatest abundance $41 \%$, followed by Chamaephytes, Therophytes, Geophytes, Phanerophytes and Cryptophyte with 25\%, 23\%, 4\%, $4 \%$ and $3 \%$ of species were the dominant life forms of the area. In terms of geographical distribution, the Irano-Turanian plant species with $64 \%$ obtained the maximum value. († JASEM
\end{abstract}

http://dx.doi.org/10.4314/jasem.v21i3.23

Keywords: Flora, Geographical distribution, Life form, Raunkiaer.

\section{INTRODUCTION}

Due to the importance of the subject in Iran, a lot of studies have been conducted on the flora and species composition in different regions of the country, all of which centralized on the preparation and measurement of the floristic list (number of species) and plant cover structure in terms of family and life forms. Study on vegetation has been useful in the resolution of ecological problems such as biological conservation and natural resource management. Based on the results, future changes can be predicted. Moreover, the understanding of plant elements contained in one area is considered as the underlying principle for other researches. Iran, due to its remarkable climatic variations, is confronted with different ecosystems each having specific characteristics and different inter-relations. Recognizing the immense resources and understanding the relationships between plants and factors affecting them, are important in order to maintain the consistency and stability of this part of the national wealth. In the case of shrubs and their impact on the community, it suffices to note their role in the expansion of production in the community, providing the possibility to use rangelands multipurposely, and increasing ecological stability (Koocheki et al., 2008).
Mousavi, (2004) in a floristic study in Khanchay Tarom watershed in Zanjan came to the conclusion that 71 percent of plants belonged to the IranoTuranian region. Among the life forms Hemicryptophytes and Therophytes respectively had accounted for the highest percentages. Ashrafi et al., (2004) by the assessment of the flora in Varamin region identified 202 plant species, in which IranoTuranian plants showed the highest dispersion. Kashipazha et al., (2004) by studying the the flora of Bagheshad found that $85.29 \%$ of the species belonged to the Irano - Turanian region. In the assessment of life forms, they concluded that Hemicryptophytes and Therophytes were the most frequent life forms of the region. A great deal of previous research could be found on vegetation studies in different climates and locations which testify to the significance of this research, among which the readers are kindly refered to (Atashgahi et al., 2004; Dolatkhahi et al., 2011; Tovichi, 2011; Kazemian et al., 2004; Gholami et al., 2006; Ghollassi Mood et al., 2006; Memariani et al., 2009; Dinarvand et al., 2015).

According to the importance of the botany and identification of the flora in different sciences such as agriculture, biology and pharmacy, this study set out to evaluate vegetation characteristics in Baharkish rangeland which is important in terms of medicine 
plants and forage production for a large part of the livestock in Khorasan Razavi Province. These studies are important for accessing specific plant species in a certain time and location, determination of rangeland's potential vegetation growth, the possibility of increasing vegetation density, identification of resistant, threatened or endangered species, determining the country's vegetation, the possibility of achieving new plant species, and identification of destructive factors for vegetation cover of the given area. The aim of this study is to provide basic floristic information to identify plant species for preservation, restoration and development of Quchan Baharkish Pastureland in Khorasan Razavi Province, IRAN.

\section{MATERIALS AND METHODS}

Geographical location and climatic conditions of the region: Baharkish rangeland lies between 5840 and $5836 \mathrm{E}$ and 3644 and $3642 \mathrm{~N}, 60 \mathrm{Km}$ away from south Quchan and the central part of Doghaei rural district, with an area of 1035 ha (Figure 1). The average height of the area is about 2069 meters above sea level (with minimum of $1740 \mathrm{~m}$ maximum of $2440 \mathrm{~m})$. To undertake this study, an area of approximately 200 ha was selected in Baharkish rangeland.
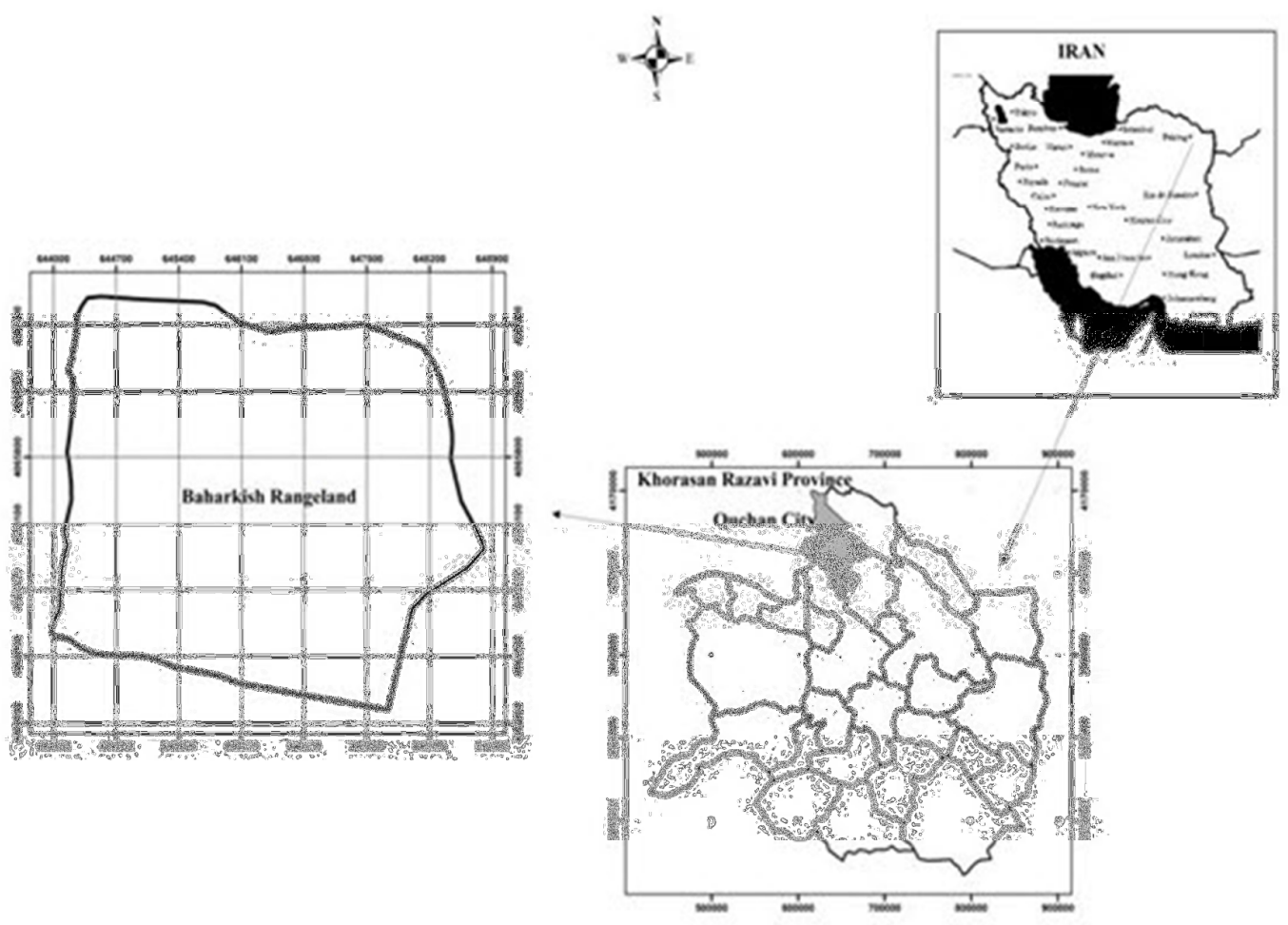

Fig. 1- Location of Baharkish rangeland in Quchan, Khorasan Razavi Province, IRAN

According to the long-term climate data from synoptic stations of Quchan city (data record from 25 years period in Evaporation measuring station of Aryeh and rain gauge station of Akhlamad), average annual precipitation and annual evaporation were estimated at $337 \mathrm{~mm}$ and $998.2 \mathrm{~mm}$, respectively. Average annual temperature is $9.4^{\circ} \mathrm{C}$ with the lowest and highest monthly values in January as well as July and August. Figure 2 shows the Ombrothermic diagram of Baharkish pasture. It can be seen that the dry period in Baharkish pasture is about 5 months, which starts from mid-May until late October (Annual report meteorological organization, 2013; Ministry of energy, 2013). 


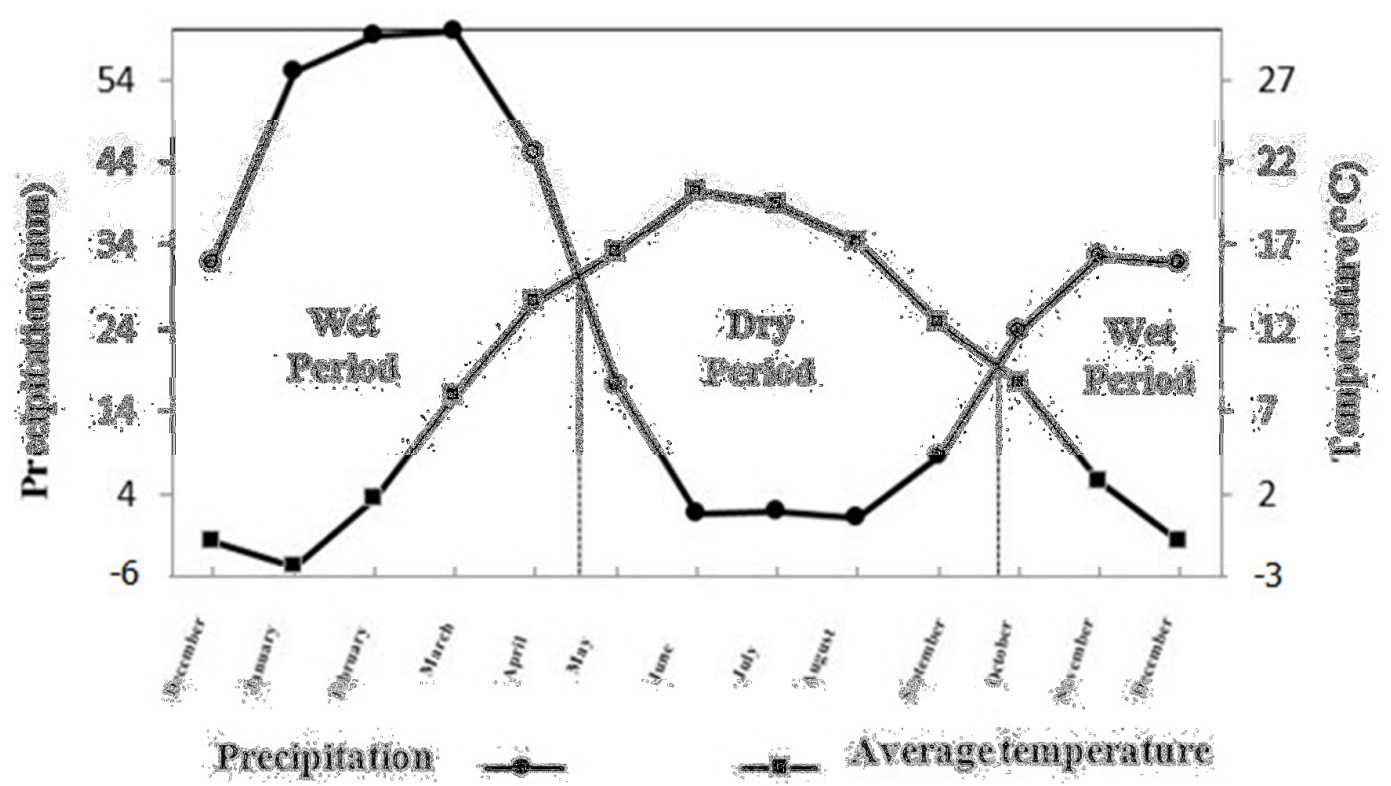

Fig. 2- Ombrothermic curve of Baharkish rangeland in Quchan based on long-term climatic data

Sampling Method: All maps (topographic map in the scale of 1:25000; geological map in the scale of 1:100000; Aerial photos in the scale of 1:20,000; and satellite images related to Baharkish rangeland in Quchan) were superimposed on four maps of slope gradient, aspect, hypsometry, and geological formations in the GIS software Arcmap 10.2 software environment, to produce working unit map, and 13 working units were determined. During the field surveys and vegetation sampling in spring 2014 a total of 10 plots were placed random systematicly in each unit. Plots with 2 square meters were used according to the Minimal area method (Aghaalikhani \& Qushchi, 2005). Plot positions were also recorded using GPS in the U.T.M (Universal Transverse Mercator) Corrdination system.

Identification of Life form and chorology of plant species: During the field surveys in the spring of 2014, plants were collected, and dried using newspaper under pressure, then transfered to Natural Resources organization, Khorasan Razavi Province for further identification. This stage was accomplished according to the available resources and conventional methods using identification keys. (Rechinger, 1967-1998، Townsend \& Guest, 19661985، Zohary, 1966-1972، Davis, 1965-1988 ، Boissier, 1867-1888، Komarov, 1934-1954 'Assadi et al., 1988-2011 ، Ghahreman, 1979-1992، Maassoumi, 1986-2000 ، Ghahreman, 1994، Mobayen, 1975-1996 ، Mozaffarian, 2003 \& Mozaffarian, 2005). Classification of plant life forms was performed based on the Raunkiaer (1934) system. In this system, plants are classified into five categories of phanerophytes Chamephytes,
Hemicryptophytes, Geophytes and Therophytes. In addition, the geographical distribution of plants were obtained following (Léonard, 1988), (Zohary, 19631973) and (Takhtajan, 1986).

\section{RESULTS AND DISCUSSION}

The floristic study in baharkish rangelands resulted in the identification of 22 families and 77 species. These families include poaceae (18\%), Asteraceae (13\%), Laminaceae (12\%), Fabaceae (9\%), Apiaceae (8\%) and Brassicaceae (6\%). Hemicryptophytes represent the most frequent life form in the area, with the Cryptophytes as the least frequent life form. Roughly $41 \%$ of the plant species are hemicryptophytes, $25 \%$ Chamaephytes, 23\% Therophytes, 4\% Geophytes, $4 \%$ Phanerophytes and 3\% Cryptophytes. In terms of geographical distribution, $64 \%$ of the plant species belong to the Irano-Turanian geographical growth form, while other species could be found in other vegetation growth areas throughout the country. Based on the findngs of this study, 77 plant species have been identified which have formed different plant communities in reaction to their ecological conditions and applied managements over the years (Table 1). 
Table 1- List of scientific names of species, life forms and geographical distribution of plants in Baharkish

\begin{tabular}{|c|c|c|c|}
\hline Scientific name & Plant family & Life forms & Chorology \\
\hline Acantholimon avenaceum & plumbaginaceae & $\mathrm{Ch}$ & IT \\
\hline Acanthophyllum bracteatum & Caryophyllaceae & $\mathrm{Ch}$ & IT \\
\hline Acroptilon repens & Asteraceae & $\mathrm{He}$ & PL \\
\hline Aeluropus littorallis & Poaceae & $\mathrm{He}$ & IT, M, SS \\
\hline Allium xiphopetalum & Alliaceae & $\mathrm{Cr}$ & IT \\
\hline Alyssum linifolium & Brassicaceae & Th & IT, M \\
\hline Anchusa arvensis & Boraginaceae & $\mathrm{He}$ & IT, M \\
\hline Arrhenatherum kotschyi & Poaceae & $\mathrm{Ge}$ & IT \\
\hline Artemisia aucheri & Asteraceae & $\mathrm{Ch}$ & IT \\
\hline Artemisia khorassanica & Asteraceae & $\mathrm{Ch}$ & IT \\
\hline Asperula glomerata & Rubiaceae & $\mathrm{Ch}$ & IT \\
\hline Astragalus podolobus & Fabaceae & $\mathrm{Ch}$ & IT \\
\hline Astragalus verus & Fabaceae & $\mathrm{Ch}$ & IT \\
\hline Atraphaxis spinosa & Polygonaceae & $\mathrm{Ch}$ & IT \\
\hline Avena fatua & Poaceae & $\mathrm{Th}$ & IT,ES \\
\hline Boissiera squarrosa & Poaceae & Th & IT, M \\
\hline Brassica napus & Brassicaceae & $\mathrm{He}$ & PL \\
\hline Bromus tectorum $\mathbf{L}$. & Poaceae & Th & PL \\
\hline Bupleorum exaltatum & Apiaceae & $\mathrm{Ch}$ & IT \\
\hline Carex stenophylla & Cyperaceae & $\mathrm{He}$ & PL \\
\hline Carthamus lanatus & Asteraceae & Th & IT \\
\hline Ceratocarpus arenarius & Chenopodiaceae & Th & IT \\
\hline Cichorium intybus & Asteraceae & $\mathrm{He}$ & PL \\
\hline Colutea buhsei & Fabaceae & $\mathrm{Ph}$ & IT, ES \\
\hline Convolvulus arvensis & Convolvulaceae & $\mathrm{Th}$ & $\mathrm{SCO}$ \\
\hline Cotoneaster ovatus & Rosaceae & $\mathrm{Ph}$ & IT \\
\hline Cousinia eryngiodes & Asteraceae & $\mathrm{He}$ & IT \\
\hline Crambe kotschyana & Brassicaceae & $\mathrm{He}$ & IT \\
\hline Dactylis glomerata & Poaceae & $\mathrm{He}$ & PL \\
\hline Dianthus orientalis & Caryophyllaceae & $\mathrm{Ch}$ & IT \\
\hline Dorema amoniacum & Apiaceae & $\mathrm{He}$ & IT \\
\hline Echinops ritrodes & Asteraceae & $\mathrm{He}$ & IT \\
\hline Elymus hispidus & Poaceae & $\mathrm{He}$ & IT, ES, M \\
\hline Ephedra major & Ephedraceae & $\mathrm{Ph}$ & IT, ES, M \\
\hline Eremurus luteus & Liliaceae & $\mathrm{Ge}$ & IT \\
\hline Eruca sativa & Brassicaceae & $\mathrm{Th}$ & IT, M, ES \\
\hline Eryngium caucasicum & Apiaceae & $\mathrm{He}$ & IT \\
\hline Euphorbia aucheri & Euphorbiaceae & Th & IT \\
\hline Ferula ovina & Apiaceae & $\mathrm{He}$ & IT \\
\hline Festuca valesiaca & Poaceae & $\mathrm{He}$ & IT,ES \\
\hline Glycyrrhiza glabra & Fabaceae & $\mathrm{He}$ & IT,M \\
\hline Gundelia tournefortii & Asteraceae & $\mathrm{He}$ & IT \\
\hline Heliotropium khorassanicum & Boraginaceae & $\mathrm{Th}$ & IT \\
\hline Hordeum bulbosum L. & Poaceae & $\mathrm{Cr}$ & IT, M \\
\hline Hulthemia persica & Rosaceae & $\mathrm{Ch}$ & IT \\
\hline Krascheninikovia ceratoides & Chenopodiaceae & $\mathrm{Ch}$ & IT \\
\hline Lagochilus cabulicus & Lamiaceae & $\mathrm{Ch}$ & IT \\
\hline Linaria lineolata & Scrophulariaceae & $\mathrm{He}$ & IT \\
\hline Malcolmia strigosa & Brassicaceae & $\mathrm{Th}$ & IT \\
\hline Medicago rigidula & Fabaceae & $\mathrm{Th}$ & IT \\
\hline Melica persica Kunth & Poaceae & $\mathrm{He}$ & IT \\
\hline Nepeta bracteata & Lamiaceae & Th & IT \\
\hline Noaea mucronata & Chenopodiaceae & $\mathrm{Ch}$ & IT, ES, M \\
\hline Nonea caspica & Boraginaceae & $\mathrm{Th}$ & IT \\
\hline Onopordon leptolepis & Asteraceae & $\mathrm{He}$ & IT \\
\hline Perovskia abrotanoides & Lamiaceae & $\mathrm{Ch}$ & IT \\
\hline Phalaris minor & Poaceae & $\mathrm{Th}$ & Cosm. \\
\hline Phlomis cancellata & Lamiaceae & $\mathrm{He}$ & IT \\
\hline Pimpinella tragium & Apiaceae & $\mathrm{Ch}$ & IT, ES, M \\
\hline Plantago major & Plantaginaceae & $\mathrm{He}$ & $\mathrm{SCO}$ \\
\hline Poa bulbosa & Poaceae & $\mathrm{Ge}$ & IT,ES,M \\
\hline Prangos latiloba & Apiaceae & $\mathrm{He}$ & IT \\
\hline Reseda lutea & Resedaceae & $\mathrm{Th}$ & IT,SS \\
\hline Salvia limbata & Lamiaceae & $\mathrm{He}$ & IT \\
\hline Sanguisorba minor & Rosaceae & $\mathrm{He}$ & IT,M,ES \\
\hline Scariola orientalis & Asteraceae & $\mathrm{Ch}$ & IT \\
\hline Serratula latifolia & Lamiaceae & $\mathrm{He}$ & IT \\
\hline Silene chaetodonta & Caryophyllaceae & $\mathrm{He}$ & IT \\
\hline Stachys lavandulifoia & Lamiaceae & $\mathrm{He}$ & IT \\
\hline Stipa arabica & Poaceae & $\mathrm{He}$ & IT \\
\hline Teucrium polium & Lamiaceae & $\mathrm{Ch}$ & IT,M \\
\hline Thymus transcaspicus & Lamiaceae & $\mathrm{Ch}$ & IT \\
\hline
\end{tabular}




\begin{tabular}{cccc} 
Trifolium repens & Fabaceae & $\mathrm{He}$ & IT \\
Trigonella monantha & Fabaceae & $\mathrm{Th}$ & IT,ES,M \\
Verbascum agrimoniifolium & Scrophulariaceae & $\mathrm{He}$ & $\mathrm{IT}$ \\
Veronica khorassanica & Scrophulariaceae & $\mathrm{He}$ & IT \\
Vulpia persica & Poaceae & $\mathrm{Th}$ & $\mathrm{IT}$ \\
\hline
\end{tabular}

Ch: Chamaephyte, Cr: Cryptophyte, Ge: Geophytes, He: Hemicryptophyte, Ph: Phanerophyte, Th: Therophyte Cosm. : Cosmopolite (cosmopolitan), ES: Euro-Siberian, M: Mediterranean, PL: Pluriregional, SCO: Subcosmopolitan, SS: Saharo-Sindian, IT: Irano-Turanian

There have been identified 22 families and 77 plant species in the floristic list for the area. On account of geographical distribution identified plants could be categorized in Irano-Turanian with $64 \%$ (greatest proportion); Irano-Turanian and Euro-Siberian and Mediteranian with $8 \%$; Irano-Turanian and Mediterranian with $8 \%$; Pluriregional with $8 \%$; Irano-
Turanian and Euro-Siberian with 4\%; Irano-Turanian and Mediterranian and Euro-Siberian with $2 \%$; Subcosmopolitan with 2\%; Irano-Turanian and Mediterranian and Saharo-Sindian with $1 \%$; cosmopolitan with $1 \%$; Irano-Turanian and SaharoSindian with $1 \%$ of the total area (Figure 3).

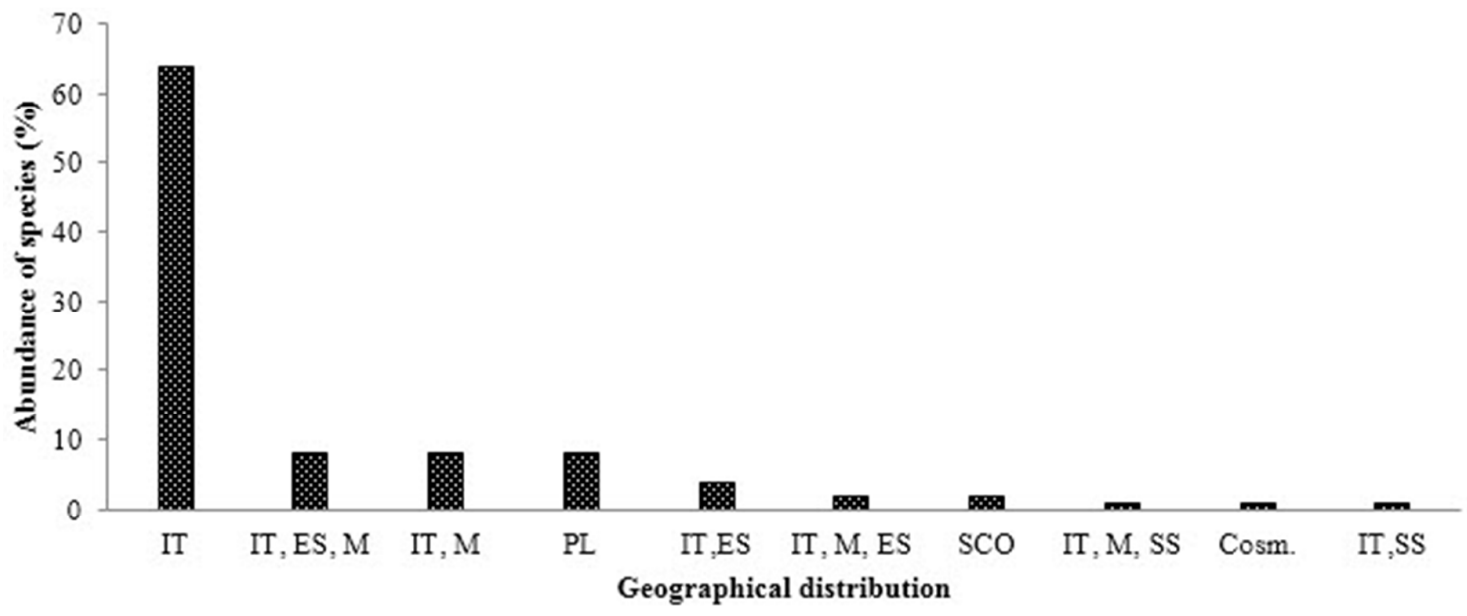

Fig. 3- Abundance of geographical distribution of plants in Baharkish rangeland ES: Euro-Siberian, IT: Irano-Turanian, M: Mediterranean, Cosm: Cosmopolite (cosmopolitan), SS: Saharo-Sindian

Classification of vegetation types according to the Raunkiaer (1934) showed that Hemicryptophytes plants accounted for the largest share with $41 \%$, followed by Chamaephytes 25\%, Therophytes 23\%, Geophytes $4 \%$, Phanerophytes $4 \%$ and Cryptophytes 3\%. (Figure 4). 


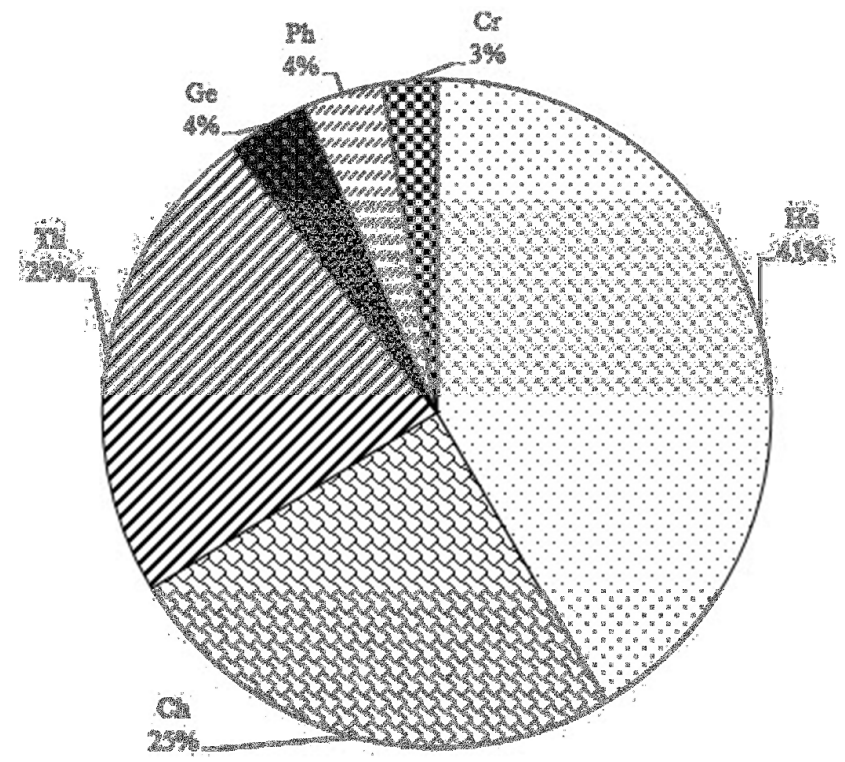

Fig. 4- Pie chart of life forms percentage of the species in Baharkish rangeland

Ph: Phanerophyte, Ge: Geophytes, Cr: Cryptophyte, Ch: Chamaephyte, Th: Therophyte, He: Hemicryptophyte

From the 77 species identified, 22 families were prevalent in the study area, including Poaceae with 18\%, Asteraceae 13\%, Lamiaceae 12\%, Fabaceae 9\%, Apiaceae $8 \%$, Brassicaceae $6 \%$ followed by 5 families included Boraginaceae, Caryophyllaceae, Chenopodiaceae, Rosaceae, Scrophulariaceae with 4\%, and 11 families included Alliaceae, Convolvulaceae, Cyperaceae, Euphorbiaceae, Ephedraceae, Liliaceae, Plantaginaceae, plumbaginaceae, Polygonaceae, Resedaceae and Rubiaceae with 1\% (Figure 5).

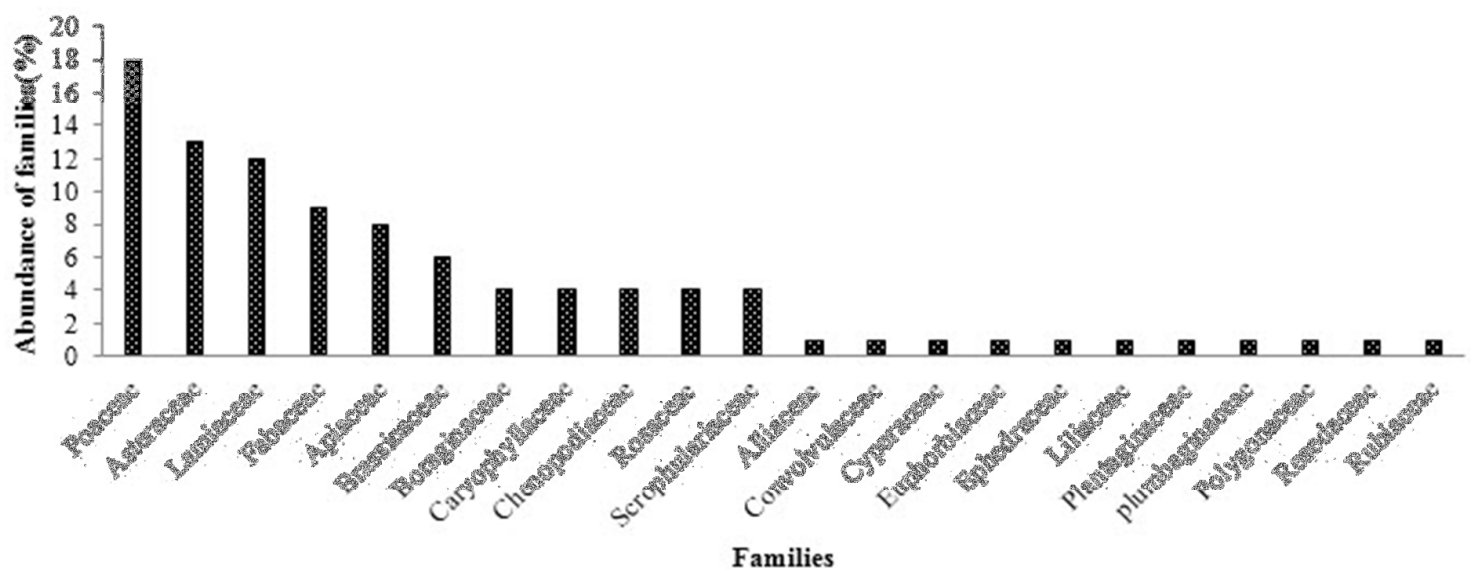

Fig. 5- Abundance of plant species distribution for different families in Baharkish rangeland

Actual floristic composition of a vegetation community forms in response to different environmental conditions and vegetation's reactions based on its ecological potential. The flora of Baharkish rangeland in Quchan has been firstly evaluated in this study and 77 species from 22 families have been identified.

There are remarkable differences in terms of precipitation, temperature, and other climatic parameters. This remarkable variation has resulted in current species richness, since climatic, edaphic, and topographic factors are the major influencers for vegetation cover in different natural domains (Moghadam, 2005; Baghestani Meibodi, 1997). The study of vegetation and geographical distribution of different plant species could help identify the area's ecological potential from different aspects, and yet is an influential factor in the assessment of status future condition, and hence it could inform a better management. Baharkish rangeland is located in the southern boundaries of Quchan urban district and in the central parts of the Doghaei rural distric. Given the 22 families identified, current study has show that Poaceae with $18 \%$ and Asteraceae with $13 \%$ are the 
dominant plant families in the area. These families, at the same time, constitute a major share of plant communities in Iran. Studies conduceted by Naghipour Bourj et al., (2011) on the floristic condition of desert rangeland in arid parts of Iran has showed the relative dominance of these two families. Mehrnia et al., (2014) by applying the Raunkiaer life form assessment method showed the important share of the Hemicryptophytes. In this regard Archibold, (1995) relates the existence of Hemicryptophytes to the cold and mountaneous climate the area which could partly explain the dominance of this life form in Baharkish rangeland. Zarezade et al., (2007) also found that Hemicryptophytes shape a large part of life forms in Damgahan rangelands in Yaz Province. In terms of geographical distribution, Irano-Turanian region with $63 \%$ had the largest proportion. Javanshir, (1980) belived that geographical distribution of a plant community reflects the influence of different vegetation growth areas. Basaed on the chorological study, Irano-Turanian plant species forms the largest proportion, Habibi et al., (2013) which is consistent with the findings of Vaseghi et al., (2008). In the latter study on the lifeforms and geographical distribution of plant species in the highlands of Kalat-Zirjan, Gonabad, it was shown the prevalence of Therophytes and Hemicryptophytes life forms and Irano-Turanian vegetation growth area.

Conclusion: Iran with a wide diversity of topography, geology and climate conditions is considered as one of the most important areas in terms of plant diversity and speciation. In general, the study results showed that Baharkish region has a diversity flora of pasture, medicinal and industrial plants. Most of these plants are very important in terms of health benefits. The domestication of these plants can not only eliminate the pharmaceutical industry's need for natural active ingredients, but can also reduce the risk of extinction by decreasing the utilization pressure.

\section{REFERENCES}

Aghaalikhani, M; Qushchi, F (2005). Translation: Applied Plant Ecology. Islamic Azad University of Varamin Pishva. First Edition.

Annual report meteorological organization (taken from the Meteorological Office of Khorasan Razavi), manuals statistics from (2001 to 2013). first edition, 16 volumes.

Archibold, OW (1995). Ecology of world vegetation. Champman and Hall Inc. London, 509 p.

Ashrafi, K; Asadi, M; Najari, R (2004). Introduction to the flora, life form and plant geographical distribution of Varamin region. Pajouhesh \& Sazandegi No: 62 pp: 51-63.
Assadi, M. Ed.(1988-2011). Flora of Iran. Research Institute of Forests and Rangelands, Tehran (In Persian).

Atashgahi, Z; Ejtehadi, H; Zare, H (2009). Study of floristics, life form and chorology of plants in the east of Dodangeh forests, Mazandaran province, Iran. Iranian Journal of Biology. 22(2): 193-203.

Baghestani-Meibodi, N (1996). Vegetation-Soil relationships: on arid and Semiaird rangelands.research institute of Forests and Rangeland. P.46.

Boissier, PE (1867-1888). Flora Orientalis. Vols. 1-5. Genevae et Basileae. H. Georg, Geneva.

Davis, PH (1965-1988). Flora of Turkey and the East Aegean. vols. 6 and 8. Edinburgh University Press, Scotland.

Dinarvand, M; Ejtehadi, H; Jankju, M; Andarzian, M (2015). Iranian Journal of Plant Biology, p.14.

Dolatkhahi, M; Asri, Y; Dolatkhahi, A (2011). Floristic Survey Arjan - Parishan Protected Area in Fars. Journal taxonomy and biosystematics, 2(9):31-46 (In Persian).

Ghahreman, A (1979-1992).Colorful flora of Iran. Research Institute of Forests and Rangelands, Tehran (In Persian).

Ghahreman, A (1994). Plant systematics: cormophytes of Iran. Center for Academic Publication, Tehran (In Persian).

Gholami, A; Ejtehadi, H; Ghassemzadeh, F; Ghorashi-al-Hosseini, J (2006). Study of plant biodiversity around protected area of the Bazangan Lake. Iranian Journal of Biology 19: 398-407 (In Persian).

Ghollassi Mood, Sh; Jalili, B; Bakhshi Khaniki, GR (2006). Introduction to flora and life forms of plants in west of Birjand. Pajouhesh and Sazandegi 73: 65-73 (In Persian).

Habibi, M; Sattarian, A; Ghorbani Nohooji, M; Gholam Alipour Alamdari, E (2013). Introduction of floristic, life form and chorology of plants in the ecosystems of Paband national park, Mazandaran province. Journal of plant ecosystem conservation. 1[3]: 47-72.

Javanshir, K (1978). Atlas of woody plants of Iran. Departmentof Environment Press. 
Kashipazha, A.M., Asri, Y., Moradi, H.M. (2004). Introduction to the flora, lifeformes and Chorology of Bagheshad Region, Iran. Pajouhesh \& Sazandegi No 63 pp: 95-103.

Kazemian, A; Saghafi, F; Assadi, M (2004). Floristic study of Bande-Golestan and identification biological forms and chorotypes of plants. Pajouhesh and Sazandegi 64: 48-62 (In Persian).

Komarov, VL. Ed (1934-1954). Flora of USSR. Vols. 1-30. Izdatel'stvo Akademi Nauk SSSR Leningrad (English translation from Russian, Jerusalem, 1968-1977.

Koocheki, A; Aghaalikhani, M; Nassiri, M; Khiabani, H (2008). Translation: Biology and Utilization of Shrublands. Cyrus M. Mckell.Ferdowsi University of Mashhad. $833 \mathrm{p}$.

Léonard, J (1988). Contribution a l'étude de la flore et de la végétation des desert d'Iran, Fascicule 8: Étude des aries de distribution, Les phytochories, Les chorotypes. Bulletin of the Jardin Botanique National de Belgique, Meise.

Maassoumi, AA (1986-2000). The genus Astragalus in Iran. Vols. 1-4. Research Institute of Forests and Rangelands, Tehran (In Persian).

Mehrnia, M; Ramak, P (2014). Floristic investigation of Noujian Watershed (Lorestan province). Iranian Journal of Plant Biology 6(20): 113-136 (In Persian).

Memariani, F; Joharchi, MR; Ejtehadi, H; Emadzade, $\mathrm{KH}$ (2009). Contributions to the flora and vegetation of Binalood mountain range, NE Iran: Floristic and chorological studies in Fereizi region. Ferdowsi University International Journal of Biological Sciences 1(1): 1-17 (In Persian).

Ministry of energy statistics meteorological stations and evapo. (Taken from the Meteorological Office of Khorasan Razavi). Statistical manual of (2013), first edition, $624 \mathrm{p}$.

Mobayen, S (1975-1996). Flora of Iran: vascular plants. Vols. 1-4. Tehran University Press, Tehran (In Persian).

Moghadam, MR (2005). Pasture and rangeland. The second edition, Tehran University Press. 470 pages.
Mousavi, A (2004). An Introduction of Flora and Phytogeographical Elements of Khanchay Watershed in Tarome-olya of Zandjan. Iranian J. Natural Res. 57[3]: 551-563.

Mozaffarian, V (2003). A dictionary of Iranian plant names. Farhang Moaser Publication, Tehran (In Persian).

Mozaffarian, V (2005). Plant classification. Vols 1-2. Amirkabir, Tehran (In Persian).

Naghipour Borj, AA; Haidarian Aghakhani, M; Tavakoli, H (2011). Investigation of flora, life forms and chorotypes of plants in the Sisab protected area, North Khorasan province (Iran). Sciences and Techniques in Natural Resources 5(4): 113-123 (In Persian).

Raunkiaer, C (1934). Life forms of plants. Academic Press, Oxford.

Rechinger, KH (1967-1998). Flora Iranica. Vols. 1176. Akademische Druck und Verlagsanstalt, Graz.

Takhtajan, A (1986). Floristic regions of the world. University of California Press, California.

Tovichi, Zh (2011). Identify flora and plant life in the hive in East Azerbaijan Province. Agricultural Science Journal of Islamic Azad University, Tabriz, 4(14): 23-40 (In Persian).

Townsend, CC; Guest, E (1966-1985). Flora of Iraq. Vols. 1-9. Ministry of Agriculture and Agrarian Reform, Baghdad.

Vaseghi, P; Ejtehadi, H; Zokaei, M; Joharchi, MR (2008). Floristic studies, life forms and chorology of plants in Kalat highlands of Gonabad, Khorassan Razavi province, East of Iran. Journal of Science (Tarbiat Moallem University) 8(1): 75-88 (In Persian).

Zarezadeh, A; Mirvakili, SM; Mirhossaini, A (2007). Introduction to the flora, Life form and plant geographical distribution of Darrah Damgahan in Mehriz Yazd.

Zohary, M (1966-1972). Flora Palaestina. Jerusalem Academic Press.

Zohary, M (1973). Geobot anical Foundations of the Middle East. 2 vols. Gustav Fischer Verlag Stuttgart 